Technologies of the Sky: A Socio-Semiotic and Critical Analysis of Televised Weather Discourse ${ }^{1}$

\author{
Phillip Vannini ${ }^{2}$ \\ Aaron M. McCright ${ }^{3}$
}

${ }^{1}$ Direct correspondence to: Phillip Vannini, School of Communication and Culture, Royal Roads University, Victoria BC V8W 5Y2, Canada. Email: vannini@lycos.com.

${ }^{2}$ Phillip Vannini is a research fellow in the School of Communication and Culture at Royal Roads University. He has published research on popular culture and semiotics in such journals as Symbolic Interaction, CTheory, The Journal of Popular Culture, and Studies in Symbolic Interaction.

3 Aaron M. McCright is an assistant professor in the Lyman Briggs School of Science, Department of Sociology, and Environmental Science and Policy Program at Michigan State University (mccright@msu.edu). He has published work on power, ideology, social movements, and environmental problems in such journals as Social Problems and Environmental Politics. 


\title{
Technologies of the Sky: A Socio-Semiotic and Critical Analysis of Televised Weather Discourse
}

\begin{abstract}
We offer a critical reading of televised weather reporting and forecasting discourse. We analyze text obtained from the US affiliate station of The Weather Channel over three days when a winter front advanced through the United States. Our critical analysis reveals the underlying ideological character of weather representation. We interpret the practice of weather representation within the context of the hegemonic discursive orders of leisure, consumption, capital accumulation, and risk management through the technologization of discourse - which characterize contemporary postindustrial culture. Through an analysis of the interpretive practices of a small viewer community, we demonstrate that while alternative readings of weather discourse are possible, they nevertheless are shaped by the technologization of weather discourse. We conclude by promoting socio-semiotics and critical discourse analysis as promising theoretically guided methodologies for analyzing discourse on the environment.
\end{abstract}

Keywords: Weather; Discourse; Semiotics; Media; Technology; Environment. 


\section{In fair Weather prepare for foul.}

\section{Thomas Fuller (1732)}

An obvious way in which humans relate to their biophysical environment is through everyday weather. Whether we live on a coast, in the mountains, in a desert, or on a plain, we all experience some kind of weather. Indeed, talking about such weather is often the easiest and safest way to initiate a conversation with strangers and acquaintances. Whereas our direct experience of the weather is clearly localized, we can virtually experience weather elsewhere in the world through media representation. Weather reporting and forecasting clearly are important within mass media discourse. Detailed information on local and global meteorological conditions, often accompanied by colorful maps and historical statistical information, typically fills an entire page or more in most local and national newspapers. Also, regular radio weather reports are particularly meaningful to many people - especially drivers and boaters — who often depend on them for safe travel.

But, television is the mass medium where weather reporting and forecasting (and weather discourse more generally) takes center stage and is made more spectacular. Producers of television weather discourse combine visual stimuli that are especially appealing to viewers with a wealth of written and spoken textual information. Almost all network television stations and some cable networks (e.g. Cable News Network) heavily incorporate weather reporting and forecasting into their news programs to an extent that weather discourse often trumps other news concerns (e.g., the economy, international politics, sports) for programming time. Other cable networks — such as those owned by Discovery Communications, Inc. (e.g., Discovery Channel, The Learning Channel, and The Travel Channel)—even feature weather documentaries in which exceptional weather phenomena are often portrayed in a dramatic and even sensationalist tone. Also, major weather-related, special effects-rich motion pictures like Twister, The Perfect Storm and The Day After Tomorrow in recent years have achieved considerable success at the box office. In 1982 this blossoming "weather business" saw the birth of a 24-hour television channel dedicated exclusively to the weather: The Weather Channel (hereafter, TWC), with its numerous international affiliates in the English-speaking world. 
Despite our seemingly universal lay preoccupation with everyday weather conditions and exceptional meteorological phenomena and despite the institutionalization of weather discourse within the mass media, weather discourse receives scarce attention within social science. Social scientists regularly analyze such phenomena as environmental values, attitudes, and behaviors and the causes, impacts, and solutions of environmental problems (e.g., Dunlap and Michelson 2002). Indeed, several theorists argue that core values of order, control, and instrumental rationality embedded within Western culture facilitate the objectification and exploitation of the environment. Several scholars identify the cultural origins of these "anti-environmental” values in Western science since Descartes and Bacon (e.g., Merchant 1980) and Judeo-Christianity (e.g., White 1967). However, such scholars rarely examine the socialization agents and processes through which these abstract values are internalized by social actors. For instance, social scientists largely neglect the practice of media weather reporting and forecasting (for exceptions, see Ross 1991; Ungar 1999).

We address this lacuna with a systematic analysis of the production and consumption of media weather reporting and forecasting. We argue that such an examination may provide critical insight into the production and reproduction of ideological discourses regarding science, technology, risk, information production and consumption, entertainment, and ultimately the interaction between humans and their biophysical environment - a relationship of interest to cultural and environmental scholars alike. We posit that the dominant discursive orders of our postindustrial society play a crucial role in the way producers represent the weather and in the way people understand the meanings of weather discourse.

Media weather discourse - in its spectacular dramatization — contributes to the constitution of the subjectivity of the weather as a socio-cultural, historical, geo-political, and ideological phenomenon, as well as the subjectivity of "weather-citizens," those who experience meteorological conditions everyday and consume their representations (Ross 1991). The sky, if you will, is the ultimate frontier to be conquered by the society of the spectacle (Debord 1977; Kellner 2003). By assigning use, exchange, symbolic, and sign-exchange value to the weather and to its ideological representations, the hegemonic 
groups that control the oligopolistic information market colonize the weather and put it to work in the global exchange of commodities.

We demonstrate the foundations of our argument through a socio-semiotic and critical analysis of television weather discourse. Our paper is divided into three parts. In the next section we briefly examine the weather as a cultural phenomenon and lay out our theoretical framework. After describing our methodology, in the second section we offer our interpretation of selected segments of three days of weather discourse on TWC. In the third section we offer a brief account of a set of alternative readings of weather discourse by analyzing the interpretive practices of an online community of TWC viewers. In our conclusion, we offer a final word on the meanings of weather discourse and the relevance of critical discourse analysis and socio-semiotics for examining discourse about the environment.

\section{Understanding Weather Representation: Socio-Semiotics and Critical Discourse Analysis}

The weather has an obvious use value for humans. The rhythmic alternation of sun and rain obviously permits resource growth and survival of the species. But societies assign other kinds of value to the weather. Many cultural theorists, for example, emphasize the symbolic value of environmental or

natural phenomena. In the process, they stress that social meaning regarding the biophysical environment resides within our interpretations of ecological phenomena, which may or may not follow closely from the biophysical conditions themselves (e.g., Burningham and Cooper 1999; Macnaghten and Urry 1998). As such, cultural scholars argue that we may learn much about human groups by analyzing their environmental discourse - i.e., their interpretations of and myths about their biophysical environment. For instance, Mary Douglas (1975) finds that social groups living in geographic proximity but culturally separated by geophysical barriers (such as a river or a mountain chain) assign different and sometimes diametrically opposite meanings to the same meteorological events. Because the weather is a symbolic system, Douglas argues that social scientists need a better phenomenological understanding of weather conditions that is historically, socially, and culturally contingent.

We believe that the weather has assumed sign-exchange value in contemporary Western capitalistic societies. In other words, different weather conditions and especially their mediated 
representations carry both economic exchange value and symbolic value based on their positioning in a system of weather-related commodities. As Andrew Ross (1991) explains, this is possible because of the ideological representation of the weather in our contemporary media culture. Ross argues that our postindustrial society has incorporated weather reporting and forecasting into existing dominant orders of discourse and that hegemonic (military, scientific, and corporate) technocrats play a critical role in defining this inherently political discourse. Such hegemony, however, is resisted by countercultural communities operating at the fringes of society: e.g., cyberpunks; hackers; New Age groups; and ecowarriors. Through various oppositional readings of mass-mediated information and alternative uses of technology, these groups contest what Ross (1991) identifies as a techno-fascist culture. Among these groups are "weather junkies," or people fascinated with weather reporting and forecasting. Ross (1991) asserts that their alternative lifestyle practices clearly demonstrate that the ideological discourses of science and technology are subject to deconstruction and resistance.

By suggesting that mediated representation of the weather is highly ideological, we claim that weather discourse plays an important but often neglected role in the functioning of the "consciousness industry"- the complex of interlocking interests of transnational corporations and oligopolistic information-exchange markets (Smythe 1981). The mass media today take an active role in shaping the consciousness of their audiences (by shaping their beliefs, attitudes, values, and agendas), because their commercial interest is to sell such audiences to advertisers. For Smythe (1981:7-8), the "secret" underlying the growth of the consciousness industry resides in:

(1) The relation of advertising to the news, entertainment, and information material in the mass media;

(2) The relation of both that material and advertising to real consumer goods and services, political candidates, and public issues;

(3) The relation of advertising and consumer goods and services to people who consume them;

(4) The effective control of people's lives which the monopoly capitalist corporations dominating the foregoing three sets of relationships try to establish and maintain. 
The ideology of the consciousness industry then is the illusory belief system that the system of information and the system of commodities production and exchange are interdependent. "The commercial mass media are advertising in their entirety" (Smythe 1981:8, emphasis in original), and the common goal of the media, advertisers, business organizations, and political institutions is that of maintaining such a hegemonic status quo through cultural — rather than military, for exampledomination (Smythe 1981; also see Gramsci 1971).

In contemporary society, we argue, cultural domination increasingly takes certain characteristics typical of the "spectacle" identified by Debord (1977). Debord's metaphor - while not entirely accurate for the analysis of our case, as we explain later-is certainly suggestive. Debord argues that the spectacle can inform our understanding of a society organized around the production, distribution, and consumption of images and commodities. For Debord (1977) the spectacle works as a tool of pacification and depoliticization, as a constant opiate turning potentially creative subjects into passive audiences mesmerized by a seductive power that freezes their thought and action. The society of the spectacle is one of mystifying appearances, a masquerade of simple relations into specialized mediations and representations informed by entertainment, pseudo-information, and consumption. By separating workers from their labor, art from life, and consumption from human needs the spectacle hypnotizes and demands submission, conformity, and the cultivation of commodified pseudo-uniqueness.

The spectacle is also marked by an expansionary dynamic, by a drive to colonize new symbolic spaces and permeate all realms of desire and everyday life with its ethos of endless leisure and consumption. The spectacle, therefore, plays an instrumental role in fostering the hegemonic control of culture and society by the hands of oligopolistic media organizations and transnational corporations. The spectacle, in other words, is the modus operandi of the consciousness industry. When weather conditions and their representations are turned into commodities and appearances, the society of the spectacle has been successful in extending its ideology onto our relation with the physical environment. Therefore, when the weather and its representations are put to work for the consumer system, the capitalist hegemony is renovated and strengthened. 
As said, however, Debord's (1977) metaphor has its limitations, and we must somewhat distance ourselves from it. In fact, whereas Debord (1977) utilizes a rather monolithic and universalizing concept of the spectacle, we follow Douglas Kellner (2003) and subscribe to a more localized view of contextspecific spectacle(s) marked by the complexity of their inherent contradictions. For Kellner (2003) spectacles assume different characteristics dependent on temporal and spatial boundaries. For example, spectacular representations of media weather speak volumes about the country in which they are produced. Weather coverage in Canada suffers less from the sensationalism typical in American media discourse. Weather reports in Europe and Australia are extremely localized, as opposed to the globalizing pretensions of TWC in the United States, which prominently features weather maps of entire continents in one screenshot - thus betraying American-centric views of the globe.

Perhaps even more importantly for Kellner (2003), spectacles are fraught with dynamics of contestation that detract from the omnipotence that Debord imputed to them. Spectacles such as that of weather discourse are unpredictable, contingent, and may even backfire on its orchestrators. This is possible, in part, because current media configurations offer interactive possibilities to audiences. In this sense audiences may labor in two distinct senses. First, media audiences labor by reproducing the material conditions that make their conditions of employment possible through their consumption (Smythe 1981). In other words, audiences "do work" when they turn their leisure time into labor by exposing themselves to media messages, by consuming the images and commodities offered to them, and thus by renovating the dynamics of consumerism (Smythe 1981). Second, media audiences labor (at times) by actively interacting with media discourses and thus posing themselves not as passive subjects but instead as "technosubjects" (Kellner 2003) potentially able to resist the dominating force of the spectacle. Without exaggerating the interactivity of contemporary media like the Internet, Kellner (2003) still refuses to believe in the total eclipse of the subject and finds instead democratizing possibilities of involvement in all of our media culture. By arguing for both the power of the spectacle, and the power of alternative readings (however limited both forces may be), we are thus positing our understanding of the weather as a discursive realm that is open to communicative negotiation. 
If we accept the assertion that the weather is a sign positioned in a greater system of signs, we must lay out a clear semiotic framework for its interpretation. There are two levels at which semiotic undertakings can be useful for understanding weather phenomena. For instance, take the quality of cloud cover. On one (meteorological) level, for example, the quality of clouds in the sky may be indexical of an ensuing storm. There is no intentionality in clouds, or similar indexes, but there is signification. On another (communicative) level of signification and connotation, we may also use semiotics to understand intentional symbolic practices of weather representation - such as those of the media. Here we are less interested in indexes than we are in symbols, since ideology deeply informs the meanings of symbols. In addition, we are interested not only in the semiotic component of signification, but also the exo-semiotic (i.e. contextual and situational) components - in particular, those material (politico-economic) and cultural practices that dialectically shape both signification and interpretation.

Social semiotics sharply differs from Saussurean semiology (Saussure 1959), in which the relation between an object (or signified) and its representation (or signifier) is less directly mediated by interpretive processes, idealistically assuming the existence of a transcendental signified (for an elaboration of this argument see Gottdiener 1994; Hodge and Kress 1988). Socio-semioticians understand that the relations between signifieds and signifiers and between signs are not rooted in idealism. Signs have different meanings; hence, they are said to be polysemic. Thus, socio-semioticians turn their attention to the study of signifieds and of the material conditions and socio-political consequences of interpreting the polysemic property of signs and sign systems at a time in history when signification and interpretation are inevitably influenced by the hegemonic practices of mass media (Gottdiener 1985, 1994; Hodge and Kress 1988; Kress and Hodge 1979; Kress and van Leeuwen 1996). Critical discourse analysis (CDA) shares with socio-semiotics a similar concern: the analysis of the relation between ideology, power, and signs (for a review see Fairclough 1995b; Grimshaw 2001; Van Dijk 2001). Like CDA researchers, socio-semioticians are heavily influenced by the ideas of Gramsci (1971) on hegemony, Volosinov (1973) on the socio-political “organization” of meaning, Bakhtin (1981, 1986) on genres, Althusser (1971) on ideology, and Foucault $(1972,1980)$ on discourse. In this paper we 
employ a Foucauldian CDA theory and methodology elaborated by Fairclough (1989, 1992a, 1992b, 1993, 1995a, 1995b).

Following Halliday (1978), Fairclough sees texts as spaces in which processes of social interaction, individual cognition, and representation coexist. The constitutive force of texts derives from this property of multifunctionality. Complexes of texts and discourses constitute discursive orders. These discursive orders in turn fashion the subjectivity of their consumers (Foucault 1972). But while discourse and discursive orders do form subjectivities and social practices, the opposite is also true; discourses are shaped by the practices of social subjects. Consequentially, if we see discourse as a form of symbolic practice, discourse analysis can be understood as "the analysis of how texts work within sociocultural practice" (Fairclough 1995a:7). This approach to the study of discourse implies we study the "dialectical relationship between a particular discursive event and the situation(s), institution(s) and social structure(s) which frame it" (Fairclough and Wodak 1997:55), and especially how these frames are “ideologically shaped by relations of power and struggles over power” (Fairclough 1995a:132). Sociosemiotics and CDA complement each other well, since the latter is based on the ontological assumptions of the former (Vannini 2004). In this article we use the analytical framework of CDA to study weather discourse on TWC, and we use socio-semiotics to study the practices of a specific interpretive community — as well as to derive conclusions on the socio-cultural significance of weather discourse.

\section{Methods}

Winter weather in the United States is marked by a continuous succession of high and low pressure fronts that are the object of much attention on TWC and other media. A small number of these weather events garner heightened attention during the winter season. However, the weather "happens" everyday, and events such as substantial blizzards and sustained below $0^{\circ} \mathrm{F}$ (or $-18^{\circ} \mathrm{Celsius}$ ) temperatures are quite infrequent between the uneventful alternation of sun and clouds and more or less mild temperatures. In order to capture the mundane character of everyday weather discourse we did not select any extraordinary phenomenon for our analysis. Rather, we focused on the coverage of a relatively minor trough of low pressure advancing through the Midwest, Southeast, and Northeast regions of the United 
States. We videotaped, observed, and transcribed segments from eighteen hours of TWC coverage from January 17 through January 19, 2003. To illustrate our interpretations in the following section, we discuss only a few selected excerpts (see Appendix) which were chosen to maximize the narrative coherence of our representation of TWC discourse. Our sampling is theoretical and aimed at analytical goals (see Glaser and Strauss, 1967:45) rather than representative and aimed at generalizability.

Nevertheless, on the basis of our observations of TWC programming over time-preceding and following data collection —we note great consistency in the development of a consistent discourse over time. As is customary in Fairclough's (1992b, 1995a) analytical framework for CDA, we report our observations at three levels: textual description, discursive practice interpretation, and socio-cultural explanation.

Regrettably, much discourse analysis focuses on the production of text, neglecting practices of distribution and consumption. Critical ethnographies of text consumers are indeed quite sparse, and it is no accident that much too often audiences are still perceived as gullible media dopes (Becker 2002). The consumption and use of discourse ought instead to be seen as a critical interpretive process that has a clear emancipatory potential for interpretive communities (Denzin 1992). As socio-semioticians, we understand the complexities of both signification and interpretation. Therefore, we provide the reader with our critical analysis of weather discourse on TWC as well as an overview of the interpretive practices of a small community of TWC viewers. With the latter, we report on the extent to which the ideological representations of weather on TWC influence the nature of the viewers' practices. This helps us understand how the mass media as a socialization agent facilitates the internalization of such cultural values as order, control, and instrumental rationality vis-à-vis the environment.

We make no claim regarding the representativeness of this sample of viewers. Indeed, TWC may have no meaningful designation of its "typical viewer." We merely offer a gaze upon the practices of an interpretive community engaged in the process of making sense of information within a locally contingent background (Fish 1981; Peirce 1960). In order to do so, as we conducted our observation of TWC coverage of the above-mentioned low-pressure front, we also recorded a number of message threads simultaneously posted on public bulletin boards by visitors at TWC's official Internet website. Others 
(e.g., Schultz 2000) theoretically conceive and empirically examine Internet bulletin boards as interactive media for public discussion. We analyzed 185 messages for form and content (Fairclough 1995a). Later in our paper, we offer our reading of these interpretive practices, together with a broader contextualization of their significance and more information about this interpretive community.

\section{Virtual Storm-Chasing on The Weather Channel}

TWC in the United States depends on weather reports and forecasts from the U.S. National Weather Service (NWS). Over the last two decades, TWC adapted its programming and developed from a ridiculed cable television curiosity to perhaps the most influential and commercially successful national media source of weather and weather-related information. From its initial service of weather reporting and forecasting, TWC evolved into an all-around weather discourse medium covering a broad range of topics. These topics are treated in relation to minute-by-minute weather developments, thus often dramatizing the spirit of otherwise placid activities like gardening or golfing.

At writing time, TWC in the United States regularly features weather maps or individual weather segments for the following interests and topics: aches and pains, air quality, allergies, aviation, boating and beach-going, cold and flu, daily traveling, driving, finances, gardening, golfing, homemaking (for indoor heating and cooling), national parks, school, skiing, skin protection, special events, sporting events, and vacation planning. These accompany the omnipresent and more traditional reports—shortterm and seven-day forecasts at the state, national, and continental level. In addition, TWC produces drama-documentaries, like Storm Stories and Atmospheres, which are prime-time, one-hour segments on real stories of the lives of people affected by exceptional weather events. TWC also offers more information on demand. For instance, recent technological advances now make it possible for weather enthusiasts to receive a relatively accurate and constant flow of information on their computer desktop and handheld device, via email, Internet video, and by web-enabled cell phone and wireless text messenger. Air travelers and ground commuters can also receive up-to-the-minute personalized weather information by providing information on their current location and travel trajectory. This wealth of 
information is the object of our interest. By observing the continuous weather coverage on TWC we attempt to capture the multi-dimensionality of weather discourse.

In the remainder of this section, we discuss selected excerpts of our transcription of January 18, 2003, TWC programming presented in the Appendix. The 9:00 AM PST edition of the program Weather Center opens with the top story of the day - the cold temperatures and snow clouds hovering above the Southeast, Northeast, and Midwest United States. Lines 1 through 41 of the transcription cover approximately five minutes of this edition of Weather Center. As is customary for Weather Center, TWC's staple program, the top story is accompanied by a series of current meteorological observations and forecasts. These alternate with recently recorded images of areas affected by exceptional weather. After a brief look at record cold temperatures in the South and a glance at the high pressure system bringing warm temperatures and sunny skies to the West coast (not included in the transcript), the program heads for its first commercial break (line 43-53) prior to the local report and forecast. Weather Center resumes at approximately 9:10 AM with its "Lifestyles" segment followed by another commercial break (lines 55-104). We transcribed the text in lines 106 to 132 from the 6:00 PM edition of Weather Center. Lines 106 to 111 contain the opening of this edition, while lines 113 to 132 contain an excerpt of its "Lifestyles" segment.

Our first observation deals with the discursive representation of the snow falling across the country. In lines 33 to 35, Weather Center's host announces that the forecast calls for more snow. This announcement is accompanied nonverbally by a look of disgust and the verbal claim that "some of us just don't want to see any more snow." The snow, together with cold temperatures, seems to be the clear antagonist of this ongoing "bad" weather narrative. This impression is reinforced in lines 106 to 111 when by late evening the snow is said to have caused considerable damage and delays. But an opposing discursive ideological formation exists, and it can clearly be noticed by examining lines 62 to 87 . Here the snow is a blessing (line 72), it is fun (lines 62 and 84), and its forecast now brings a smile to the host's face (line 83). This is an important finding and one that allows us to see clearly the relation between hegemony and the weather. Frequently, institutions house two opposing ideological discursive 
formations in struggle with one another and associated with different discursive forces, thus making a hegemony nothing but an "unstable equilibrium” (Fairclough, 1995a:76; also see Althusser 1971; Gramsci, 1971).

A discursive order, such as that of weather forecasting and reporting, is the heterogeneous and unstable structure resulting from the provisory emergence of certain discursive practices over opposing others. In this instance it is obvious that snow accumulation serves a utilitarian economic function for the commercial services that benefit from it (e.g., mountain resorts, tour operators, winter gear manufacturers), but a negative function, for example, for the smooth operation of others who depend on timely and safe transportation of goods and persons. Fairclough refers to the textual manifestation of this hegemonic struggle between ideological discursive formations as interdiscursivity. This concept points to the heterogeneity of texts, their property of being constituted by combinations of elements from different discourses and genres. In other words, the complexity and contradictions of discursive practices find their manifestation in the heterogeneity of text. An interdiscursive analysis therefore needs to show "how texts selectively draw upon orders of discourse - the particular configurations of conventionalized practices (genres, discourses, narratives, etc.) which are available to text producers and interpreters in particular social circumstances" (Fairclough 1995a:188 [emphasis in original]). But whether snow accumulation actually brings profit or loss, its reporting and forecasting is directly informed by the features of the hegemonic discursive orders of capitalistic and consumer culture. In other words, snow assumes meaning and value in relation to the function it plays for our capitalistic system and consumer culture. This, of course, is the underlying hypothesis of $\mathrm{CDA}$ - the manifestation of mutually shaping interconnections between text, discursive practice, and socio-cultural practice.

Texts draw not only from different discourses but also from different genres (Bakhtin 1973, 1981; Fairclough 1992a, 1995a). Weather discourse on TWC mainly draws from the genres of news reporting, entertainment, scientific research reporting, advertising, and colloquial conversation. In our contemporary media culture all of these genres have been shaped by the logic of the spectacle (Kellner 2003). Some excerpts from our analyzed text illustrate this. For proper legitimation, TWC offers 
authoritative reporting through a combination of strategies derived from the genres of scientific analysis and news reporting. Program hosts on TWC are credentialed meteorologists who utilize information obtained from increasingly complex, computer-generated models. Weather Center hosts dress professionally and base their observations on analyses of complex and spectacular weather maps displayed in their production studio. Not only does this differ remarkably from the ethnometeorological practices of a not-so-distant past, whose traditional intuition is now displaced by increasingly scientific and technological accuracy, but it also sharply differs from the colloquial discussion of the weather by non-professional "weather gals," which was typical of television until TWC became popular (Ross 1991). Consider, for example, the wealth of information on local weather given by TWC. Most viewers are probably puzzled by the vast statistical information on the UV index, dew point, barometric pressure, and so forth. Such wealth of information connotes the might of science in its aura of seductive mystery over the layperson. And it is precisely this spectacle of scientific information that gives the report/forecast a sense of authoritativeness, legitimacy, and credibility from which TWC benefits - by increasing its audience and consequently its advertising income.

However, weather reporting on TWC is not filled with the scientific jargon we might expect from a meteorological report. Such an account would arguably bore, confuse, and estrange most viewers. Weather reporting on TWC must entertain as well as inform (see Postman 1985) and weather science must be mainstreamed to appeal to a large audience. In other words, the weather must be neatly packaged and marketed as a commodity. To achieve this, the genre of news and scientific reporting has to overlap with that typical of sensationalistic journalism in which the accuracy of information is accompanied by spectacular imagery, personal drama, entertaining narrative, and even traces of the informal conversational tone that used to characterize earlier media weather discourse. The clearest example of this on the TWC is the program Storm Stories, whose promo is reported in lines 95 to 104 . The style of the promo itself derives from the genre of movie trailers, with its sped-up vocal and visual delivery and heightened sense of personal drama, all with the rapid succession of spectacular imagery depicting the weather as an almighty and awesome force deserving undivided attention. In sum, weather 
representations assume exchange value in relation to how spectacular they can be made. In this system of weather conditions as images/commodities, a "good" storm story is one that causes the most viewers to think and behave as consumers.

Elements of this logic of spectacle (Kellner 2003) also creep into TWC's staple program Weather Center. Consider, for example, the opening segment of this program (lines 1 to 4). Here beautiful images of weather effects (e.g., an icy, almost surreal New York City skyline and a tranquil, almost timeless frozen fountain in Atlanta) accompany the more conventional, journalistic-style introduction to the top stories. Dramatic and sensationalistic images of mangled vehicles and traffic pile-ups accompany the opening of the 6:00 PM Weather Center (lines 106 to 111). A clear emphasis on the weather's "agency" is also manifested in different ways. For example, after the opening of the 9:00 AM Weather Center, weather reporting seems to overlap with a style of sports reporting, with an emphasis (“It's been awhile!") on the historical significance of the weather breaking record temperatures, as if the weather was the protagonist of an athletic competition (line 13). The style of informal face-to-face interaction, what Fairclough (1994) refers to as the conversationalization of public discourse, is also present in this segment through the host's use of direct address and nonverbal behavior ("New York City, you were at seven above," "heh, if you call that warmer," etc.).

This discursive and visual representation of the weather is the manifestation of utilitarian/capitalist ideology and also the constitutive moment of the commodification of the meaning of weather. The following textual segments are also exemplary of the relations among consumers, information, advertisers, and business theorized by Smythe (1981), relations that reveal how the consciousness industry maintains its hegemonic control. Consider, for example, the tone of lines 102 to 104. Here the weather is clearly promoted and sold as a commodity to which consumers are attracted because of its spectacular and entertaining qualities. The ideological character of weather reporting lies then not only in its being represented as a means for the accumulation of capital profit, but also in its profitability as an end in itself, made possible through its spectacular representation. Further evidence for this argument can be found in lines 61 to 82, where the "RSN Outdoor Update" segment lies at the 
crossroads of various genres. We can understand this segment as: (1) an advertisement for three ski resorts and for the RSN travel network; (2) a report on culture and lifestyles (e.g., skiing and the Snowfest festivity); (3) a news/consumer report on the state of tourist facilities (e.g., state of open runs and trails) and weather conditions (e.g., snow accumulation); (4) a friendly piece of advice on where to go on a trip (e.g., "grab your boots and boards"); and (5) a scientific/educational report (e.g., the temperature inversion phenomenon and the exclusive above-the-tree-line geographical location of the Sugarloaf resort). The ideology that defines the use value and exchange value of the weather is evident here. Certain weather phenomena and conditions are also clearly invested with sign exchange value. For example, exposure to either real or artificial sunlight tans the skin, and in our society a suntanned skin connotes beauty, health, and social status (Coupland and Coupland 1997; Vannini and McCright 2004).

The textual characteristics analyzed above have much significance as discursive practices. Every action at the micro level contributes in part to the reproduction of structures at the macro level as language codes are reproduced in instances of speech (Garfinkel 1967). Discourse theorist Michael Halliday (1978:2) is clear on this point: "By their everyday acts of meaning, people act out the social structure, affirming their own statuses and roles, and establishing and transmitting the shared systems of value and of knowledge." What this means in regard to CDA is that any instance of interpersonal interaction, such as textual production and consumption, can be examined in relation to its effects on larger structural processes and in relation to how these processes shape said communicative interaction.

As said before, the structural processes analyzed here in relation to weather discourse result in the formation of an interdiscursive order that combines elements from various genres and ideological discourse formations. This interdiscursive order is an alliance of the discursive practices of scientific research and hegemonic political-economic forces, and this conjunction is a manifestation of the contemporary "technologization of discourse" (Fairclough 1995a). Following Foucault's (1980) analysis of the alliance between scientific discourse and political power structures that make knowledge/power the primordial agent of transformation of reality and the subject in everyday life, Fairclough (1995a:102) defines the technologization of discourse as: 
a process of intervention in the sphere of discourse practices with the objective of constructing a new hegemony in the order of discourse of the institution or organization concerned, as part of a more general struggle to impose restructured hegemonies in institutional practices and cultures $[\ldots]$ it involves an attempt to shape a new synthesis between discourse practice, sociocultural practice and texts. This is done through a process of redesigning existing discursive practices and training institutional personnel [subjects, clients, publics] in the redesigned practices, on the basis of research into the existing discursive practices of the institution and their effectivity.

In relation to the discursive order of the weather, we see how earlier amateurish, ethnometeorological (i.e. "folk") practices are branded as inadequate by progresses in the discursive practices of science and technology. This technologization of weather discourse also results in the constitution of the meaning of weather as both a means and an end for capital accumulation. Ideological discourse formations of dominant political and economic powers - such as that resulting from the technologization of weather discourse - are quite successful at colonizing life-world practices through their instrumental strategies (Habermas 1984). In our contemporary society, these strategies result in a consumer culture where the management of risk, such as the risk of meteorological phenomena, serves clear economic functions (Beck 1992; Featherstone 1991; Giddens 1991). Information is an important commodity (Lyotard 1985) used to manage risk and is also important for a system's self-maintenance (Luhmann 1993). When public information becomes a valuable commodity for conducting everyday activities, the realm of the private and mundane is colonized by the public discursive order of hegemonic powers. For example, think of the consequences of receiving continuously up-to-date, accurate weather information on a cellular phone or other handheld device. An individual may use information as one travels to manage risk by planning and acting accordingly, thus consuming or saving more resources. Such information is thus a manifestation of the working of the consciousness industry as news on good weather drives the public to consume the products with which good weather is associated.

Meteorology and its information are used to promote consumption and facilitate capital accumulation and thus to strengthen the hegemonic status quo. They are also used indirectly through 
weather media representation to commodify the cultural meanings of the weather and instrumentalize the relationship between humans and the natural environment. Consider the relation between weather representation and commercial product promotion on TWC. Lines 43 to 88 detail clearly how everyday life is problematized through the strategic use of weather information (in this case a map showing reports of influenza by state) and medicalized through the combination of scientific discourse (orange juice contains vitamin $\mathrm{C}$ which helps combat cold and influenza) and promotional discourse (the advertising of Florida Growers' orange juice, which also sponsors the influenza map). Examples of this are quite prevalent on TWC. The allergy medication Allegra sponsors a section of Weather Center while claiming to fight certain effects of the weather (lines 50 to 58). Also, the insurance company New York Life advertises that the insurance it sells can help people prepare for changing times (lines 89 to 94). Immediately after, TWC runs a promo for its program Storm Stories that illustrates human fragility in the face of weather's destructive force. Finally, the excerpt in lines 113 to 132 is a clear example of the hegemonic ideological discourse formation in weather representation. Here bad weather (the winter season) is responsible for the onset of seasonal affective disorder. But science and consumption once again come to our rescue in a spectacular display of timely and efficient problem prevention and problem solving. The society of the spectacle thus turns natural conditions into direct advertisements for commodities and in particular the weather into reminders for its audiences that it is time to labor for the maintenance of the system.

Indeed, as weather discourse constitutes the meaning of the weather, it also works to constitute the subjectivity of weather citizens as consumers. The human subject constructed by TWC discourse is a middle-class consumer with cars, golf and ski gear, possibly a boat, sufficient money for constant selfmedication and protection from the weather, and a disposable income for regular travel. The spectacle of commodities and related weather images here also are linked clearly to the exo-semiotic (especially economic) context of weather representation. A sunny day in Australia is indirectly an advertisement for surfing, perhaps, whereas a freezing day in Edmonton, Alberta is a good opportunity to keep warm inside 
the mall. The weather spectacle thus assumes the character of greater ongoing cultural narratives that inform its meanings in differential ways.

Citizens of this weather consciousness industry are also subjects seemingly desensitized to the weather outside their living room—-passive subjects who are constantly reminded how they feel: "you are cold this morning;" "it's 32 degrees but it feels like 25;" "you'd better bundle up!" To these subjects, nature is an extraneous and menacing entity that can be understood only through the lens of the spectacle as a means for leisure when "good" weather makes consumption possible and that works as a means for entertainment in itself when "bad" weather occurs. As Ross (1991) correctly speculates, the weather subject is a consumer first and foremost. Absent in weather discourse is any possibility that nature has intrinsic value or any sort of concern with environmental degradation. Pollution and smog may occasionally capture some attention but only when they make swimming, sunbathing, or jogging in the city difficult. Nature, through this ideological weather representation, is the ultimate "Other" of our consumer culture - an "Other" to be controlled, colonized, and romanticized.

\section{An Alternative Reading: Weather “Junkies” Speak Out}

Even though hegemonic ideological forces do shape signification and interpretation practices, meaning is never entirely determined. As suggested above, the ideology of the spectacle always carries contradictions and the genes of contestation. Social semiotics is particularly useful for the analysis of such complex forces. Socio-semiotics rejects the primacy of signifiers and rediscovers the importance of the signified (Gottdiener 1985, 1994; Vannini 2004). Socio-semiotics allows us to understand how meaning remains potentially open to be phenomenologically experienced in consequential ways through interpretive practices that may result in alternative readings of a text (Hodge and Kress 1988; see also Hall 1980).

Until now we have offered our own critical analysis of weather discourse on TWC with the caveat that our interpretation is not that of all viewers. Indeed, as socio-semioticians we perceive that our reading is not enough to understand the dynamics of textual consumption. Therefore, in this section we discuss a set of interpretive practices employed by some TWC viewers between January 17 and 19, 2003. 
These interpretive practices are messages posted on the public bulletin board at TWC's official Internet website. We selected the ten most popular (numerically) message threads in the "Winter 2002/2003" subcategory of the "Weather Topics" category. At writing time, this sub-category was the most popular on this website with 15,175 total messages posted since November 30, 2002. Our sample of ten message threads contains a total of 185 messages. Our analysis of the chains of messages (e.g., threads) reveals that all threads connote a discernible of skepticism toward TWC discourse. In other and simpler words these threads are virtual conversations, commentary, and "backseat" criticism of weather coverage on TWC.

Threads in the "Winter 2002/2003" sub-category are rather short in terms of temporal duration. As each day goes by, continuous new weather fronts catch website members' attention. A thread usually lasts up to 36 to 48 hours, but within that short time-span a relatively large number of messages (usually around 30) will be posted. At writing time there are 4842 registered members at TWC website, but a much smaller group of members (known as weather "junkies") is more active than most. Weather “junkies" have received this affectionate moniker over the years as TWC increased its popularity and made "weather fans" out of some viewers (Sturken 2001; Where weather 2002). No ethnographic research has investigated the everyday practices of weather junkies, and there is no demographic research on this group; thus, much of what we know is based on journalistic research or anecdotal evidence. In the remainder of this section, we provide excerpts from the bulletin board messages. We identify each excerpt with a letter and a number; the letter indicates the message thread and the number indicates the ordering of the excerpted messages within each thread. We omit any authorial identification to preserve anonymity and certain peripheral messages within threads due to space limitations.

The dominant discursive characteristic in the analyzed messages is the viewers' alternative reading of weather representation. Consider this segment excerpted from the thread titled "New Euro:"

A1: A little more aggressive with the Wed/Thu. storm for the east coast. Today's track runs from NE TX.(1014MB) at 12Z Wed. to off Hatteras (1004MB) by $12 \mathrm{Z}$ Thu. This is a little stronger and further north than yesterday's North Central TX to S. S.C. track. A perfect snow track for me 
in SE VA. But if it gets much closer we'll get more into the rain/mix area.

http://www.sca.uqam.ca/models/ecmwf_amer/cep00_9panel.gif

Post A1 cites a reading of a weather report/forecast obtained from the Atmospheric Sciences Group website at the University of Quebec, Montreal (ASG-UQM). The ASG-UQM obtains weather reports and forecasts not from the National Weather Service (NWS) as TWC does but rather from its own meteorological observations. This viewer apparently accessed a weather source different from TWC to gain more weather-related information. The website address at the end of the message is a link to a detailed meteorological map that is contrasted by this viewer with the information obtained from TWC.

Similar discussions of the plausibility of TWC reporting and forecasting are very common among the messages we collected. Consider, for example, the following:

B1: We got 1-2 inches here near BWI. This is what I was thinking before they put up those Winter Storm Warnings. Was thinking 2-4 for DC, not sure what they got yet, haven't heard, and 6-12 for Salisbury to OC which sounds a bit high, any idea what those areas ended up with?

B2: I was in 5 to 7 and... barely 2 in.! Oh well, I got a cheap snowday!

B3: Forecast: 3-6". Result: 1/2"

B6: Our weather guys started "STORM WATCH" two days before and everyone got all hyped up. The grocery stores were out of milk and bread. Typical Memphis. The rain started and it rained and rained and rained. At $11 \mathrm{am}$ the rain was over and the weather guys were saying it missed us BUT they STILL closed the schools two hours early! My daycare closed at 4:30 so I had to take off early from work. It did finally snow and dusted rooftops but that was it. The snow that did fall was beautiful. Huge flakes large enough to see the detail!! The streets were completely DRY but I guess they just wanted to be safe in case there were icy spots. It just seemed silly to close everything down but that's Memphis for you. It's supposed to "flurry" tomorrow and I'm hoping it snows hard enough to run around the front yard with my daughter for a few minutes $[\ldots]$. 
Whereas A1 offers a critical reading of TWC forecasts, messages B1 through B6 utilize selfcollected information on snow precipitation in order to criticize the validity of TWC storm warnings. These messages are exemplary of the skeptical tone maintained on TWC website bulletin boards. For example, message B6 is clearly illuminating. Here we can clearly see how the technologization of weather discourse results in the colonization of everyday life. Weather information is used to manage everyday risk, and the consequences of this practice are reportedly manifested in the pre-emptive closure of schools and the emptying of grocery store shelves in Memphis. But the technologization of weather discourse has not resulted in fully silencing dissent. Alternate information sources still exist (see A1), and the hegemonic practices of TWC and the NWS are still subjected to close scrutiny by these viewers. Their scrutiny consists here in offering alternate accounts and polemical criticism of both TWC imprecision as well as the "hype" it evokes, as in the following:

C4: The funny thing about TWC is that their weekly planner maps have us in the snow. It's like they don't even care about accurate or consistent weather forecasting anymore. Their various forecasts (weekly planner, LF, website) are always different and never agree.

The skepticism found on the bulletin boards should not be read as a criticism of the possibilities of scientific discourse. If this were the case we would expect discussants to question the value of scientific models in and of themselves, and instead perhaps offer alternative explanations based on fatalistic or self-collected ethnometeorological guesses or explanations. In actuality, through their "backyard" weather observations and scientific research collected outside the TWC-NWS axis, these discussants implicitly support the technologization of weather discourse thesis. The argument could be made, borrowing from Stuart Hall (1980) that these are negotiated readings in that audience members partly accept the text's code and broadly accept TWC discourse, but somewhat modify it through interpretations that reflect their experiences, position, and interests. In other words, it is not the scientific paradigm that is under question, but rather the accurate execution of what the paradigm specifies. The point being raised here is that hype and poor expert knowledge on TWC's part make for a representation of the weather that is inaccurate. 
Besides support for the technologization of weather discourse thesis, what emerges from a reading of the practices of this interpretive community is that snow precipitation and accumulation have positive symbolic meaning ascribed by these bulletin board members. For example, take B6 once again. Even though this viewer acknowledges that snow may be an obstacle to the normal functioning of everyday life, its arrival is quite welcomed. The following thread also confirms this impression:

E1: It looks like the NWS and the local mets are seeing what many of us know-a winter storm - for Wed.N.-Sat time period. It's early so far but there is a good chance for middle TN to get another major winter storm.

E2: I hope so! They keep lowering the temps for wed-sat so maybe we'll see some more snow! E4: I hope you guys get in on it but as of this minute it's very "iffy" at best, the latest AVN run has the entire state of TN all rain.

E5: I think you guys will see some snow, it may be at the end of the storm, but it's snow nonetheless. LET IT SNOW LET IT SNOW LET IT SNOW!

Seemingly, it is not the snow in and of itself that fascinates these viewers but rather the snow as the manifestation of nature's might through a spectacular display. Weather phenomena play a central role in the definition of collective memory and in the shaping of humans' relations with their ecological habitat (Erikson 1976; Sturken 2001). Many of the members who are so eagerly cheering for the snow are also the ones discussing most other weather phenomena on this bulletin board throughout the year. In a sense then, here the aesthetic value of winter weather resides in the spectacular manifestation of its sheer force that is cause for much anticipation and excitement, as the following excerpts show:

F1: Holy crap!! Run for the hills!! 972 mb vertically stacked nor'easter a few hundred miles east of the benchmark on Friday!! Now if we could get it to trend closer to the coastline...

F2: I saw it!!!! Can you say SNOWACANE??? Were talkin historic if it does verify.

G10: It's been a good winter here. Good, but not great. We've been constantly pounded with cold arctic air (1 degree Sat. morning), but the huge trough is acting as a block, suppressing the storms 
to the south. The biggest disappointment: Thursday's storm 4-8 forecasted, we got 1 ! Give me 6+ from this next storm, and it will be a great winter!

G11: Yea, one storm that actually hits the area would restore faith in the winter world and make the winter worth something.

It is very important, however, to keep in mind that this interpretive community draws a clear line between the spectacular might of the weather-as-object and its spectacular representation mediated by TWC. This is a finding of crucial importance for socio-semioticians. If these viewers had lost interest in the weather-as-object, or the weather-signified, and instead were interested exclusively in the hyperreality of mediated representation, then this would support of the idea that the spectacle is overpowering and homogeneous. Instead, in line with Kellner's (2003) conceptualization of the contradictions inherent to the society of the spectacle and to ideology itself, we find numerous messages on these boards that are skeptical toward the value of mediated representation, criticizing it as nothing but hype, unnecessary exaggeration, drama, and fluff.

Many of these viewers argue that the sensationalistic practices to reach a larger audience undertaken by TWC in Storm Stories but also in Weather Center for example, do no justice to the weather itself. For them the weather-signified - however spectacular in its manifestation - is the story. The weather-as-object is what demands attention and not its hyperreal representation. The primacy of the signified is hereby reclaimed, and the relation between the consumer-as-laborer and the semiotic referent as image/commodity is contested. We are not suggesting here that weather junkies are in any sense "countercultural" by opposing an alternate belief system to that promoted by the consciousness industry. We are more moderately suggesting that audience labor, as intended by Smythe (1981), is not always performed in the manner preferred by information producers and marketers. Audience labor, largely because of the vast contemporary availability of information sources and because of the level of interactivity that some of these offer, may indeed be an active interpretive practice that critical discourse researchers of media need to examine more in depth. 
Consider, for example, this excerpt from a thread that we collected throughout the month of January, titled “NO MORE DOCUMENTARIES PLEASE!!!”

H1: Storm Stories and Atmospheres are on too much and in prime time. I want LIVE weather coverage when I turn on TWC. Leave the documentaries to the Discovery Channel.

H2: I agree 100\%! I have wondered the same things, as you mentioned in this as well as your other post. If we are the so-called hardcore TWC folks, and most all of us hate this programming, I wonder what demographic TWC uses to continue this run of bad television. Storm Stories once a week, maybe. But every night!! I mean how many sickies are there out there who want to continue to both watch this stuff, and also want their lives on display for the entire nation. Granted everyone wants sympathy for hardships endured, but TWC just does not seem to me to be the place to have this. As I mentioned in other posts, you are lucky to get about 10-12 minutes of actual weather every hour on the station any more. I thought this is what brought all of us to the channel in the first place. Maybe this is a way to keep OCM's from burning out, since there has been a dearth of new talent lately, but as for me I turn off TWC both during the shows and when we get the lead-ins and the aftermaths as part of the regular Weather reporting.

H5: I read somewhere that companies paid big bucks to advertise during Atmospheres. This could also be the case for Storm Stories. This would probably be the main reason for airing these shows. It doesn't matter how much you people whine and complain, as long as TWC can get the big bucks from the advertisers during these shows, the shows will continue. They are in business to make money, that is all.

H7: Evidently TWC is more concerned with potentially winning an Emmy than it is providing information.

H11: [These are] "dramatic re-enactments," which always have been, are, and will be, examples of the hokiest kind of pandering to the viewer's voyeuristic urges.

These messages clearly document that this alternative reading of the weather-signifier challenges the discursive practice of sensationalizing weather reporting and forecasting on TWC. This interpretive 
community enacts an alternative discursive practice, thus questioning the hegemony of TWC's ideological discourse formation and the very logic of the spectacle of appearances further corroborating Kellner's (2003) thesis on the society of spectacle and the notion of active audience labor. Any hegemony, after all, is but temporary and perennially unstable due to the negotiable character of the discourses used to maintain it.

\section{Coda}

Through our application of socio-semiotic principles and our analysis of the discursive practices of an interpretive community of TWC viewers, we demonstrated that the meanings of the weather and of its mediated representation are relatively open to interpretation. This is an important point because it posits a community of television viewers as an active participant in the reproduction of reality. While we do recognize the power of both semiotic and exo-semiotic processes in the constitution of meaning and the power of the media in representing cultural objects, we find that the cultural meanings of the weather are constituted by discursive orders for subjects and by these subjects through their order-producing discursive practices. Our approach allows us to reject the view that subjects are cultural dopes mastered by ideological media representations and that signifieds have lost all their pragmatic relevance due to the ideological primacy of the signifier.

While we conclude that the alternative reading practices of the small interpretive community we investigated should be interpreted as efforts to critically assess the over-sensationalistic discursive practices of TWC, we also re-state the validity of the technologization of discourse thesis (Fairclough 1995a) and the society of the spectacle thesis (Kellner 2003). The view of the weather-signified espoused by weather junkies still is an interpretation of a weather-as-object seen as a majestic natural force that can to some extent be managed through the use of technology. Use of technology, in turn, is clearly linked to availability of material means. Indeed, for all that could be said about the value and significance of audience members' alternative readings of the weather, it seems evident that their subjectivity as middleclass weather citizens, with their related habitus, remains unchallenged through their consuming practices and negotiated readings. Furthermore, while humans have failed to a large extent to control and change 
the weather intentionally, the gathering of informative discourses about the weather allows us to manage the risk associated with it. These discourses and discursive practices allow us to access weather reports and forecast information anywhere and at any time to prepare ourselves to combat exceptional weather phenomena and medicate ourselves to fight its more mundane consequences. Largely, it is through this discursive order, namely through this alliance between science and economy, that we comprehend the weather today. Thus, our work on media weather discourse helps us understand how social actors internalize values of order, control, and instrumental rationality vis-à-vis nature.

This understanding of the weather, and more generally of nature, is quite perilous for future generations. On one hand, the technologization of weather discourse speaks of the subjectification of the weather in functional-utilitarian economic terms. On the other hand, the romanticization of the weather in dramatic and spectacular terms speaks of the objectification of the weather for anthropocentric entertainment purposes. This discursive construction of nature in chauvinistic/anthropocentric terms does not bode well for both present and future concerns about environmental exploitation and sustainability (Braun and Wainwright 2001; cf., Darier 1999). Indeed, discourse researchers must continue to realize the consequential roles we can perform in discovering chauvinistic/anthropocentric ideologies in everyday discourse. Some constructivist approaches to nature are self-defeating given their nihilistic premises and relativistic conclusions (Demeritt 2002). However, through our socio-semiotic and critical analysis of weather discourse, we shed ontological and ethical agnosticism and embrace a motivated pragmatism that may serve as a future example for social scientific work in this field. We therefore promote socio-semiotics and CDA as fruitful theoretically guided methodologies for analyzing discourse on the environment.

\section{Acknowledgment}

We would like to thank Phil Graham and two anonymous reviewers for the precious help and support offered. 


\section{References}

Althusser, L. (1971). Lenin and philosophy and other essays. New York: Monthly Review.

Bakhtin, M. (1973). Problems of Dostoevsky's Poetics. Trans. by C. Emerson. Manchester, England: Manchester University Press.

Bakhtin, M. (1981). The Dialogic Imagination: Four Essays by M. Bakhtin. Ed. by M. Holquist. Austin: University of Texas Press.

Bakhtin, M. (1986). Speech genres and other late essays. Austin: University of Texas Press.

Beck, U. (1992). Risk society. Trans. by M. Ritter. London: Sage.

Becker, H. (2002). Studying the new media. Qualitative Sociology, 25, 337-343.

Braun, B., \& Wainwright, J. (2001). Nature, post-structuralism, and politics. In N. Castree \& B. Braun (Eds.), Social nature, (pp. 41-63). Oxford: Blackwell.

Burningham, K., and Cooper, G. (1999). Being constructive. Sociology, 33, 297-316.

Coupland, N., \& Coupland, J. (1997). Bodies, beaches, and burn-times. Discourse and Society, 8, 1, 7-25.

Darier, É. (1999). Discourses of the environment. Oxford: Blackwell.

Debord. G. (1977). The society of the spectacle. Detroit: Black and Red.

Demeritt, D. (2002). What is the "social construction of nature"? Progress in Human Geography, 26, 6, 767-790.

Denzin, N. K. (1992). Symbolic interactionism and cultural studies. Cambridge: Blackwell.

Douglas, M. (1975). Implicit meanings. London: Routledge.

Dunlap, R. E., and Michelson, W. (2002). Handbook of environmental sociology. Westport: Greenwood.

Erikson, K. (1976). Everything in its path. New York: Simon and Schuster.

Fairclough, N. (1989). Language and power. London: Longman.

Fairclough, N. (1992a). Discourse and social change. Cambridge: Polity Press.

Fairclough, N. (1992b). Discourse and text. Discourse and Society, 3, 193-219.

Fairclough, N. (1993). Critical discourse analysis and the marketization of public discourse. Discourse and Society, 4, 133-168. 
Fairclough, N. (1994). Conversationalization of public discourse and the authority of the consumer." In K. Russel, N. Whiteley, \& N. Abercrombie (Eds.), The authority of the consumer, (pp. 253-268). London: Routledge.

Fairclough, N. (1995a). Critical discourse analysis. London: Longman.

Fairclough, N. (1995b). Media discourse. London: Arnold.

Fairclough, N., \& Wodak, R. (1997). Critical discourse analysis: An overview. In T. Van Dijk (Ed.), Discourse and Interaction, (pp. 67-97). London: Sage.

Featherstone, M. (1991). Consumer culture and postmodernism. London: Sage.

Fish, S. (1981). Is there a text in this class. Cambridge, MA:

Harvard University Press.

Foucault, M. (1972). The archaeology of knowledge and the discourse on language. Trans. by A. M. Sheridan. London: Tavistock.

Foucault, M. (1980). Power/Knowledge. New York: Pantheon.

Fuller, T. (1732). Gnomologia. London: B. Barker.

Garfinkel, H. (1967). Studies in ethnomethodology. Englewood Cliffs, NJ: Prentice-Hall.

Giddens, A. (1991). Modernity and self-identity. Cambridge: Polity Press.

Gottdiener, M. (1985). Hegemony and mass culture. American Journal of Sociology, 90, 979-999.

Gottdiener, M. (1994). Semiotics and postmodernism. In D. Dickens \& A. Fontana (Eds.), Postmodernism and social inquiry, (pp. 155-181). New York: The Guilford Press.

Glaser, B. and Strauss, G. (1967). The discovery of grounded theory: strategies for qualitative research. New York: Aldine de Gruyter.

Gramsci, A. (1971). Selections from the prison notebooks. New York: International Publishers.

Grimshaw, A. (2001). Discourse and sociology: Sociology and discourse. In D. Schiffrin, D. Tannen, \& H. E. Hamilton (Eds.), The handbook of discourse analysis, (pp. 750-771). Oxford: Blackwell.

Habermas, J. (1984). The theory of communicative action, vol. 1. Boston: Beacon Press.

Hall, S. (1980). Encoding/Decoding. In S. Hall (Eds.), Culture, media, and language, (pp. 17-47). 
London: Centre for Contemporary Cultural Studies.

Halliday, M. (1978). Language as social semiotic. London: Arnold.

Hodge, R., \& Kress, G. (1988). Social semiotics. Ithaca, NY: Cornell University Press.

Kellner, D. (2003). Media spectacle. New York, London: Routledge.

Kress, G., \& Hodge, R. (1979). Language as ideology. London: Routledge.

Kress, G., \& van Leeuwen, T. (1996). Reading images. London: Routledge.

Luhmann, N. (1993). Risk: A sociological theory. Trans. by R. Barrett. New York: Aldine de Gruyter.

Lyotard, J. (1985). The postmodern condition. Minneapolis: University of Minnesota Press.

Macnaghten, P., and Urry, J. (1998). Contested natures. London: Sage.

Merchant, C. (1980). The death of nature. New York: HarperCollins.

Peirce, C. S. (1960). Collected papers of Charles Sanders Peirce, vol. 1-6. C. Hartshorne and P. Weiss (Eds.). Cambridge: Harvard University Press.

Postman, N. (1985). Amusing ourselves to death. New York: Viking.

Ross, A. (1991). Strange weather. London: Verso.

Saussure, F. (1959). Course in general linguistics. Trans. by W. Baskin. New York: McGraw-Hill.

Schultz, T. (2000). Mass media and the concept of interactivity. Media, Culture, and Society, 22, 2, 205-221.

Smythe, D. (1981). Dependency road. Norwood, NJ: Temple University Press.

Sturken, M. (2001). Desiring the weather. Public Culture, 13, 161-189.

Van Dijk, T. (2001). Critical discourse analysis. In D. Schiffrin, D. Tannen, \& H. E. Hamilton (Eds.), The handbook of discourse analysis, (pp. 352-371). Oxford: Blackwell.

Ungar, S. (1999). Is strange weather in the air? Climatic change, 41, 133-150.

Vannini, P. (2004). Toward an interpretive analytics of the sign. Studies in symbolic interaction, 27, $151-176$.

Vannini, P. and A. McCright. (2004). To die for. Symbolic interaction, 27, 309-332.

Volosinov, V. (1973). Marxism and the philosophy of language. New York: Seminar Press. 
Where weather junkies go for their television fix. October 10, 2002. USA Today. Retrieved January 31, 2003 from http://www.usatoday.com/weather/news/2002/2002-05-10-wx-channel.htm

White, L. (1967). The historical roots of our ecological crises. Science, 155, 1203-1207. 


\section{Appendix: Selected Excerpts of The Weather Channel Programming Transcript}

[Moving picture of New York City skyline]

MB: Take a look at a freezing New York City (.5) temperatures aren't going to make it out of the twenties today and more snow is in the forecast (1.1) [Moving pictures of Atlanta's skyline fading to moving picture of a frozen fountain] And Atlanta is also under the same breezy conditions as the Big Apple (.5) Temperatures dipped into the teens but much better forecasts are coming your way [moving pictures of two bundled-up female joggers] (0.7) Stay tuned, the weather center is up next (1.6) [Closeup of MB] Hello and thank you for joining us my name is Melissa Barrington (.) Well definitely cold across much of the eastern United States and we're going to start with the $\uparrow$ frigid northeast where this mo:rning (.) [Static picture of Northeast U.S. temperature map] look at this morning's low temperatures that we saw. (.) In Albany for example $\uparrow$ you dropped down to twelve degrees below zero! Burlington for example eighteen degrees below zero (.) and I saw earlier ((smiles)) heh Tamarac Lake <was down to thirty-three degrees below zero!> as its actual air temperature. (.4) [Picture changing to temperature chart comparing the day's temperatures with past dates. The screen is titled: It's Been Awhile!] Well it's been quite a while since we've seen numbers like this in fact look at this the morning low in Boston (.) was two above that's the coldest since January twenty-second, two-thousand (.4) New York City you were at seven above on that same year but on January eighteen, and Philadelphia eighteen degrees that was your morning low today, the coldest since January twenty-second, two-thousand. (.) [Picture changes to static Northeast U.S. temperature map] Right now, well we haven't warmed up very much at all it's only one above in Albany and Bangor (.) Thirtee:n above in Buffalo (.) twelve above in New York City and a ((smirks)) heh couple of degrees warmer (.) heh if you call that warmer in Philadelphia (.) Factor in the wind and yes there is still a lot of cold air and $\uparrow$ just a little bit of a breeze will easily give us wind chills right around zero (.) It feels like two above for example in Boston (.) fifteen below in Burlington (.) and $\downarrow$ two below in Pittsburgh (.4) $\uparrow$ Now for those of you in the Boston area (.) are you going to see a warm up? (.3) [Picture changes to a chart of five-day temperature forecast for Boston] Well it doesn't really look very good here, today though (.) twenty degrees for your high but then Sunday and Monday temperatures right around thirty degrees so slightly below average (.4) [Picture fades to images of bundled up people walking in a city] $\uparrow$ But folks here in Boston were bundling up 
earlier this morning as those overnight lows dipped into the single digits today (.) $\downarrow$ like you saw there hard to break twenty degrees but $\uparrow$ guess what? more snow is in your forecast! (.) [Picture fades to Northeast U.S. forecast map] Right now though, quiet in Boston, New York City a couple of flakes of snow coming down across parts of western New York state and then later around this evening we will see some snow showers moving across parts of the great lakes, but still staying dry here in Boston and New York but come tomorrow we're expecting widespread areas of snow from Pittsburgh Buffalo up towards Albany and also right around Boston temperatures though (.) ((smiles)) slightly warmer (.) $\uparrow$ so that's some good news ((grins in disgust)) but some of us $<$ just don't want to see any more snow $>(.6)$ [Picture changes to static temperature map of Southeast U.S.] Across the south there's also a chilly day in fact ((looks surprised)) these are some of the morning lows $\uparrow$ in fact some of them are records! (.4) Right (.3) we saw a low temperature of two above in Nashville of course you have a snowpack of seven inches on the gro:und (.) twenty-four in dallas, fourtee:n in Atlanta and Birmingham and even Thirty:Fi:ve in Orlando! [Picture changes to chart showing low temperatures in four southern cities. Screen is titled: Record Lows] (.) Here's a look at some of those records

[Commercial Video. A family is having breakfast. Picture fades to close-up of a glass being filled with orange juice. Written text on screen shows: The best start under the sun. Florida Orange Juice brought to you by Florida Orange Growers]

Background Voice: Now more than ever $\uparrow$ the best start under the sun Florida Orange Juice (.3) [Picture changes to static U.S. influenza map] This influenza report is brought to you by the Florida Orange Growers

[Commercial video shows text moving leftward across the screen being read by male voice] Have you made the move to Allegra for your seasonal allergies? ((someone sniffles)) (.) Doesn't sound like it! Allegra: for multi-symptom relief > see your doctor, for people 12 and over $<>>$ Side effects are low and may include headache, cold, or back-pain $<<$ Allegra :it's time to switch!

[Local forecast and conditions are shown] 
[Screen shows TV director's room with Allegra logo superimposed]

Background Voice: This program is brought to you by Allegra Fexofenadine HCI (.6) >Ask your doctor if Allegra is right for you< (8.5) [Picture changes to text: Weekly Planner. Screen shows image of a middle-aged Asian woman on a city street talking on a cell phone and hailing a taxi. Light music plays in background] [Switch to Close-up of MB]

MB: Hello! :and welcome back: I'm Melissa Barrington (.) Well winter definitely has a fi:rm grip on the United States this weekend (.) but ((smiles)) not everyone will be stuck insi:de (.5) Now with a look at where $\uparrow$ some of the BEST winter fun is this weekend $\downarrow$ here's our friends ((smiles)) at the RSN outdoor network. [Screen shows moving images of snowy mountains, ski resorts, people skiing throughout following segments. Each location segment is preceded by a regional map showing the resort's location]

JY: This is the RSN outdoor update (.) grab your boots and boards:: $\uparrow$ we're headed to Montana (.4) and to the deepest conditions in the state with a fifty-three inch settled base big mountain resort in whitefish has eighty:-five marked trails (.) and t:here-thousand acres of terrain open (.5) In fact the resort has been one-hundred percent open since new years' day and the powder keeps piling up! (.5) If you head to Big Mountain this weekend you may catch one of the areas' famous temperature inversions. (.5) Next, to Sugarloaf in Maine (.4) the resort has been blessed with nearly two feet of light fluffy snow since new year's (.) Skiers and riders are enjoying awesome packed powder conditions (.) one-hundred and twenty-one open trails and (blazes) and the only <lift service> above tree line skiing in the east (.7) Don't miss out on Sugarloaf annual sno:wfest (.) white white world is coming up January twentyseventh through the thirty-first (1.0) TO: HEAVENLY SKI RESORT LOCATED IN CALIFORNIA and Nevada is $100 \%$ open and that means you can ski and ride in two states without ever leaving the resort! >White Heavenly's twentyeight chairlifts (veer) interstate $<$ (.) They're all running and while snow depth ranges from forty-eight to sixty-nine inches (.) the views vary from state to state (.) from California you'll see picturesque Lake Tahoe (.) and across the state line in Nevada you'll see the Neva:da desert mountains (.5) For the weather channel I'm Todd Offenbacher. (2.0)

[Close-up of Melissa back in studio over background of forecast nation-wide map] ((smiles)) 
MB: Aww doesn't that look gre:at? It looks like a lot of fun (.) and for those of you who are ski enthusiasts (.) well (.) more snow is the forecast to move its way into <parts of the great lakes> for this weekend and then eventually as we get into early next week it'll move into parts of the northeastern US

[Commercial video showing a man and a young girl crossing a New York City street as images from the past and future are paralleled on the same screen. Epic music playing] ((deep female voice)) What sta:nds (.) the test (.3)of time? (.5) <our strongest bonds (.4) our fundamental values (.5)> (1.2) <At New York Life all humanity (.) integrity (.) and financial strength (.) provide protection and security for millions of families $>(.9)<<$ through changing times $>>$ Values that make New York Life (.) the company you keep.

[Promo for TWC Storm Stories showing images of stormy seas and waves crashing against boats and docks]

Background Voice: Monday (.4) $\uparrow$ bra:ce yourse:If for sto:rm stories (.9) See how the stormy waters of lake Michigan...(.4)

[Close-up of a middle-aged man speaking ] We saw something that was just te:rrifying (.4)

Background Voice: turn a boat race (.) into a tes:t for survival...(.4)

[Close-up of an older man speaking] $\downarrow$ I didn’t know how much time I ha:d (.6)

Background Voice: $\uparrow$ PLUS (.3) this typhoon rose to nearly $\underline{1,000}$ miles across! (.5) Watch the $\underline{\text { most }}$ $\underline{\text { intense }}$ weather images ever caught on ca:mera and a rescue (.) you have to see: to believe. (.) $\uparrow$ Watch a new series from the weather channe:1 storm stories (.4) MONDAYS at 8 eastern and pacific. ..

[Picture shows images of snow falling on city roads and highways as scenes of clean-up crews, a car accident, traffic pile-ups and slowly moving vehicles are shown] MB: Well (.) it’s called lake effect sno:w and northwestern Indiana saw plenty of it on Friday (.4) $\downarrow$ In fact twenty inches of snow fell in Chesterton, IN (.) this just to the East of Gary (.4) Near-white-out conditions made driving difficult on areas and ro:adways: and caused crews huh (.) some problems to try to keep everything clear. 
113 [Video shows picture of people walking on a city street during winter]

114 Background Voice: Seasonal Affective Disorder (.) or SAD (.) SAD shares many symptoms with

115 depression but (.) there are tell-tale signs

116 [Close up of middle-aged man speaking. Text at bottom of screen shows: Dr. Chris Riddell, MD]

117 CR: SAD almost <always ha:s the:: huh characteristics of the: (.) increased weight (.) increased sleep

118 (.4) and the:: huh carbohydrate craving (.7) Other forms of depression may ha:ve huh those

119 characteristics (.) but SAD always has them>

$120 \quad$ [Video shows people on a city street during winter]

121 Background Voice: What do you do if you're feeling the effects of SAD? (.) Anti-depressant

122 medications have proven effective and of course more light helps too

123 [Close-up of CR speaking]: And in fact some patients respond only to: light therapy (.) but most people

124 will respond to: medication management (.) which is of course less bulky and less time-consuming than

125 light therapy

126 [Video shows people walking on a city street during winter]

130 Background Voice: About $\underline{25 \%}$ of the population suffers from mild winter SAD and an estimated $\underline{5 \%}$

131 suffers from a more severe form of the disorder (.5) For the weather channel $<$ I'm meteorologist Sta:n

132 Bruno:> 